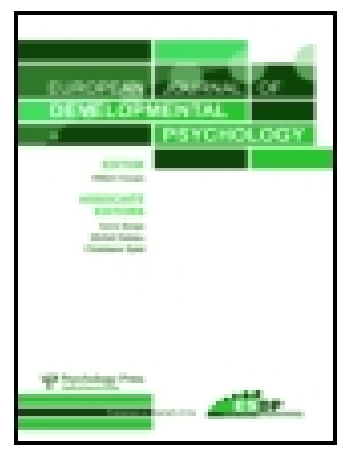

European Journal of Developmental Psychology

\title{
Cross-border mobility, European identity and participation among European adolescents and young adults
}

\author{
Davide Mazzoni, Cinzia Albanesi, Pedro D. Ferreira, Signe Opermann, Vassilis \\ Pavlopoulos \& Elvira Cicognani
}

To cite this article: Davide Mazzoni, Cinzia Albanesi, Pedro D. Ferreira, Signe Opermann, Vassilis Pavlopoulos \& Elvira Cicognani (2017): Cross-border mobility, European identity and participation among European adolescents and young adults, European Journal of Developmental Psychology, DOI: $10.1080 / 17405629.2017 .1378089$

To link to this article: http://dx.doi.org/10.1080/17405629.2017.1378089
(c) 2017 The Author(s). Published by Informa UK Limited, trading as Taylor \& Francis Group
Published online: 26 Sep 2017.

Submit your article to this journal ๘

Цll Article views: 61

Q View related articles ¿

View Crossmark data $₫$ 


\title{
Cross-border mobility, European identity and participation among European adolescents and young adults
}

\author{
Davide Mazzonia (D), Cinzia Albanesia (D), Pedro D. Ferreirab (D), \\ Signe Opermann ${ }^{c}$, Vassilis Pavlopoulos ${ }^{d}$ and Elvira Cicognani ${ }^{a}$
}

${ }^{a}$ Department of Psychology, University of Bologna, Bologna, Italy; ${ }^{b}$ Faculdade de Psicologia e Ciências da Educação da Universidade do Porto, Porto, Portugal; 'Institute of Social Studies,

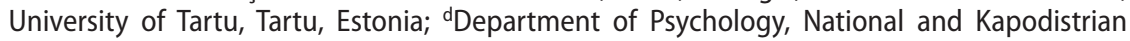
University of Athens, Athens, Greece

\begin{abstract}
Cross-border mobility is one of the most important factors that are assumed to strengthen young people's commitment as European citizens. However, the existing empirical evidence does not provide consistent support. In this paper, we tested the hypothesis that cross-border mobility is associated with a stronger European identification, more positive attitudes toward the EU, and with specific visions of the EU, and that these factors, in turn, have a positive effect on engagement at EU level. Data were collected as part of the multinational research project CATCH-EyoU. Analyses were performed controlling for gender, income, country, and migrant status. Results mostly confirmed the hypotheses among both adolescents and young adults, and for both short-term and long-term mobility. EU level participation and EU voting intentions appeared to be influenced by partly different factors. The implications of the findings, both at theoretical level and for the development of international mobility programs, are discussed.
\end{abstract}

ARTICLE HISTORY Received 18 May 2017; Accepted 1 August 2017

KEYWORDS Adolescents; young adults; active citizenship; European Union; participation; vote

\section{Introduction}

In academic and policy discourses, cross-border mobility across Europe is one of the most important factors that are assumed to strengthen young people's commitment as European citizens (Fligstein, 2008; Llurda, Gallego-Balsà, Barahona, \& Martin-Rubió, 2016; Roeder, 2011). Accordingly, the European Union

CONTACT Davide Mazzoni davide.mazzoni@unibo.it

(C) 2017 The Author(s). Published by Informa UK Limited, trading as Taylor \& Francis Group.

This is an Open Access article distributed under the terms of the Creative Commons Attribution-NonCommercialNoDerivatives License (http://creativecommons.org/licenses/by-nc-nd/4.0/), which permits noncommercial re-use, distribution, and reproduction in any medium, provided the original work is properly cited, and is not altered, transformed, or built upon in any way. 
(EU) supports free movement within its borders and the number of students taking part in some forms of education abroad (e.g., Erasmus) has appreciably increased in recent decades (European Commission, 2015). Data collected in 2011 across Europe showed that the likelihood of moving was higher among younger persons (Eurostat, 2015). People aged 15-29 years accounted for $44.4 \%$ of the total number of employed persons who moved home in the EU-28 during the 12-month period prior to the census.

The present paper, based on data from the CATCH-EyoU project, collected in eight European countries, moves from the debate about the relationship between experiencing cross-border mobility and becoming European active citizens (e.g., Muxell, 2009). More specifically, it provides empirical evidence on the relationship between adolescents' and young adults' mobility and their engagement at EU level, and it contributes to a better understanding of the psychological processes involved (see introduction to this special issue).

\section{Cross border mobility and European identity}

By'cross-border mobility' we refer in this context to physical mobility across EU countries that, differently from migration, is for an intentionally limited period, after which individuals usually come back to their home country (European Commission, 2011; Fernández, Eigmüller, \& Börner, 2016; Recchi, 2014). This kind of mobility may include, for example, visits to friends and relatives, holiday/ vacation, attending conferences and conventions, participating to exchanges or international educational programs, etc. Even if incidences of young people making involuntary migrations do exist in Europe (often as the result of regional disadvantage and absences or mismatches of personal skills and educational capital) the present study will focus on young Europeans who voluntarily move between member states for an intentionally limited time and who are typically highly educated and well-skilled (Hauvette, 2010).

Young people mobility can occur for a wide range of motives, but mobility for education purposes is probably the most investigated, due to its potential transformative and formative impact (Tran, 2016). The possible outcomes of spending a period during such crucial developmental period, in one or more countries other than their country of origin, are very wide and cover many domains, like learning outcomes, linguistic abilities, and career orientation (Gerner \& Perry, 2000; Stronkhorst, 2005). Moreover, some evidence exists that mobility promotes autonomy, competence in achieving goals and gaining control, that are typical development tasks, preventing also isolation and alienation (Pickup et al., 2015).

In the last decades, an increasing number of scholars examined the relevance of mobility for the development of young people European identity. Most explanations make reference to theoretical approaches which share the emphasis on the significance of communication and interaction between people of different national and cultural backgrounds (Maiworm \& Over, 2014). Deutsch's theory of 
social communication provided valuable insights into this process of community-building and group identity (see also Fligstein, 2008). Deutsch and other 'transactionalists' emphasized the importance of 'social communication' as a means of identity-formation, both within the nation-state and within transnational communities (Deutsch, Burrell, Kann, \& Lee, 1967). By'social communication' or 'transactions', these authors referred to the development of sustained and wide-ranging face-to-face interactions across different groups). The creation of networks that bring people together in a multitude of ways is thus important for the emergence of a shared identity and sense of belonging to the EU community.

Social psychological research further developed this perspective, by focusing on the psychological processes that can explain the relationship between cross-border mobility and the formation of a EU identity, such as the intergroup contact (Allport, 1954) and the intergroup identity model (Gaertner, Dovidio, \& Bachman, 1996). The'intergroup contact hypothesis'theorizes that positive intercultural interactions may develop, under certain conditions, by bringing people from diverse linguistic and cultural backgrounds together. The outcome of contact would be favourable when participants were of equal status, were pursuing common goals, and were backed by social and institutional support (see also Amir, 1969). The 'common ingroup identity model' adds that cooperative contact should reduce the salience of group distinctions while at the same time favouring the adoption of a superordinate identity, including both ingroup and outgroup (Gaertner \& Dovidio, 2000).

Consistently with these perspectives, several studies have focused on the international experiences of students to investigate the role of mobility in enhancing dimensions of European citizenship (e.g., positive attitudes toward the EU and European identity). For example, King and Ruiz-Gelices (2003) found that British students who spent a year studying in continental Europe were more pro-European and held a stronger European identity than students who did not study abroad. Fernández et al. (2016) found that transnational experiences in general (including practices like interactions with migrant EU-citizens even without physical border crossings) increased pro-European sentiments. Mitchell (2012) reported that Erasmus experience contributes to attitudinal changes about Europe, highlighting significant differences between Erasmus students and those who do not study abroad with respect to levels of support for the EU, interests in various aspects of Europe and identification as European. Moreover, participation in an Erasmus exchange was significantly and positively related to European identity (Mitchell, 2015), underscoring the significance of transnational contacts. Finally, Siklodi (2015) comparing visiting EU and home students argued that'the dichotomy of passive/active (EU) citizens is likely to be determined by mobility' (p. 831) and identified active citizens as those who are mobile, hold a civic EU identity vs. passive citizens as stayers, holding a cultural (national) identity.

However, the role of cross-border mobility in strengthening European citizenship has not found support in all the studies (Sigalas, 2010; Wilson, 2011), leading some authors to a critical view on the processes that are assumed to explain 
its effects (Kuhn, 2012; Merkwan \& Smith, 1999; Papatsiba, 2005). Focusing on British outgoing Erasmus students and continental students studying in UK, Sigalas (2010) did not find support for this association; moreover, he found that long-term mobility may sometimes be associated with homesickness, resulting in a stressful experience.

In the present work, we assessed the duration of mobility (less than 2 weeks, generally associated - among adolescents and young adults - with activities such as tourism and short term educational programmes, and more than 2 weeks, most likely associated with educational programmes such as Erasmus and short term work experiences), hypothesizing, in line with Recchi (2014), that longer cross-border practices exert a more marked effect. Moreover, we considered also if the mobility was performed for educational/training reasons or not.

\section{Cross-border mobility and vision of EU as a community}

Especially due to recent events (e.g., Brexit), the issue about what we expect from the future of the EU and whether and how the EU can be transformed to better respond to the changing needs of the member states, has increased in importance in public debates and at political level. However, only a minority of studies have started to address citizens' representation of the EU and the role and functions that the EU should play. In one of the rare studies on this topic, involving young people from different European countries who were studying or working abroad, Hauvette (2010) found that participants adopted a range of criteria to describe their European identity (including history, economic specificities, political systems, ethics, and others) and some of these criteria were also used to describe their ideal united Europe. Spannring, Wallace, and Datler (2008) referred to the Erasmus generation as the one who assisted to the 'transformation of European integration from being purely economic to having more political and social policy dimensions' (p. 483). Thorpe (2008) suggested that traveling across EU countries allows to cumulate European cultural capital, that is associated with more sophisticated and complex understanding of Europe and the EU.

In the present research, following Thorpe's suggestion, we tested the hypothesis that the experience of cross border mobility would strengthen a multifaceted vision of EU, conceived as a community based on a range of dimensions (i.e., shared values, history, economic and political).

\section{European identification, visions of the EU and participation}

The relationship between social identity and civic and political participation has been long investigated in the literature (e.g., Cicognani \& Zani, 2015; Fowler $\&$ Kam, 2007). One of the core ideas is that, the more individuals identify with a social group, the more they will act to defend its interest (Ellemers, 1993). 
Moreover, within community psychology there is an extensive evidence on the association between sense of belonging and identification with a community and civic participation (e.g., Albanesi, Cicognani, \& Zani, 2007; Talò, Mannarini, \& Rochira, 2014). Consistent with this literature, we thus hypothesized that a higher identification with Europe and more positive attitudes toward the EU predicted higher participation on EU issues.

A similar reasoning can be proposed for the intention to vote. Results about the 2014 European parliamentary elections showed that a high proportion of the younger group (under 25) explained their vote referring to 'European reasons' and, more specifically, to 'being in favour of the EU' and feeling European (or citizen of the EU) (European Parliamentary Research Service [EPRS], 2014). For this reason, we hypothesized that individuals with a higher identification with Europe and more positive attitudes toward the EU were also more willing to vote at the next EU elections.

Individuals' participation may also represent a way for expressing and communicating specific visions. At this regards, some authors (La Barbera, 2015; La Barbera, Cariota Ferrara, \& Boza, 2014) showed that having a project-based EU vision (compared to historical-based one) had a significant positive effect on cooperation with EU partners. Accordingly, we expected that viewing the ideal EU as a community of people sharing common values and objectives would be more associated, than other visions of $\mathrm{EU}$, with engagement on $\mathrm{EU}$ issues and intentions to vote at EU elections.

\section{Aim and hypotheses}

The aim of the present paper was to investigate, in a large sample of European adolescents and young adults, the relationship between short- (i.e., less than two weeks) and long-term (i.e., more than two weeks) cross-border mobility and participation at EU level. By participation at EU level we refer in this context to engagement in a variety of non-formal participatory practices (i.e., sharing political content on line, volunteering, donating money) related to EU issues and to formal political participation like the intention to vote at EU parliamentary elections.

More specifically, we aimed to test whether such relationship was mediated by key psychological factors, like identification with Europe, positive attitudes toward the EU and visions about the EU as a political and shared values community. We hypothesized that both short-term and long-term cross-border mobility would be associated with a higher European identification, with more positive attitudes towards the EU, and with a multifaceted vision of the EU as a community. In turn, we expected European identification, positive attitudes toward the $\mathrm{EU}$, and the vision of the EU as a political community and a community of shared values, to enhance engagement (participation and vote) at EU level. 
Table 1. Demographics.

\begin{tabular}{lcc}
\hline Variable & Adolescents (14-19 years) & Young adults (20-30 years) \\
\hline Country (\% among each age group) & $10.3 \%$ & $16.5 \%$ \\
Czech Republic & $14.7 \%$ & $6.5 \%$ \\
Estonia & $13.0 \%$ & $10.3 \%$ \\
Germany & $12.5 \%$ & $14.1 \%$ \\
Greece & $16.3 \%$ & $18.2 \%$ \\
Italy & $13.0 \%$ & $7.9 \%$ \\
Portugal & $7.9 \%$ & $17.9 \%$ \\
Sweden & $12.2 \%$ & $8.6 \%$ \\
United Kingdom & $93.1 \%$ & $92.5 \%$ \\
Migrant/sedentary status (\% born in & & \\
country) & $42.2 \%$ & $41.0 \%$ \\
Gender (\% males) & $16.73(1.22)$ & $22.69(2.20)$ \\
Age (years) & $3.43(.72)$ & $3.26(.82)$ \\
Family income (1-4) & &
\end{tabular}

Notes: For scale variables, means and standard deviation are reported. For the other variables, valid percentages among each age-group are reported.

\section{Method}

\section{Participants}

A total of 10.041 self-administered questionnaires were collected between October 2016 and February 2017, in eight countries. ${ }^{1}$ Data were collected both through paper questionnaires (53.7\%) and online (46.3\%). The recruitment strategy was targeted to young people between 14 and 30 years old. After receiving an invitation and a presentation of the aims of the study, participants decided to take part in the study on a voluntary basis. The study was approved by ethic committees in each country. Descriptive statistics for demographic variables are presented in Table 1. Most adolescents (97.6\%) and young adults (78.9\%) who completed the questionnaire were still in some form of education.

\section{Measures}

The variables related to our specific research questions are described below.

Demographic information included - besides the country - age, gender, migrant status and family income. Participants were grouped into two groups according to age: adolescents (14-19 years old; $50.6 \%$ ) and young adults (2030 years old; 49.4\%). Migrant status was assessed asking if participants were born in the same country in which data were collected or in another country. Family income was assessed through a single item ('Does the money your household has cover everything your family needs?'); possible answers ranged from 1 (not at all) to 4 (fully).

Cross-border mobility was measured referring to the last 5 years. Shortterm mobility was measured through the item 'How often did you visit other

'Data used in this study are publicly available from AMS Acta Institutional Research Repository - University of Bologna (doi: 10.6092/unibo/amsacta/5691). 
European countries for a trip between one day and two weeks?' Possible answers ranged from 1 (never) to 5 (very often). Among young adults, we considered also a measure of long-term mobility, ${ }^{2}$ through the item 'How often did you visit another European country for longer than two weeks?'. For long-term mobility, we assessed also whether the most recent visit was performed for education/ training reasons or not.

Identification as European was measured through two items, with possible answers from 1 (strongly disagree) to 5 (strongly agree). The items were'I feel strong ties toward Europe' $(M=3.49 ; S D=1.02)$ and 'I am proud to be European' $(M=3.65 ; \mathrm{SD}=1.04)$. The inter-item correlation was very high $(r=.62 ; p<.001)$ and a mean index was thus calculated and used in the analysis.

Vision of EU was measured asking 'From your point of view, what would you like the European Union to be?' Possible answers ranged from 1 (far less) to 5 (far more). Four visions of the EU have been considered: a political community, an economic community, a community based on shared history, and a community of shared values. The intercorrelations between these items were weak $(\leq .30)$.

Participation at EU level was measured through a single item asking if, in the last year, participants took part in at least one participatory activity on issues related to the $\mathrm{EU}$, like, for example, sharing political content on line, volunteering, donating money (yes/no answers). In this way, if they reported that any of the activities they performed was 'related to the EU' they were assigned the score of 1 ; if they reported that none activities was related to the EU or that they did not participated at all, they were assigned the score of 0 . Moreover, we assessed participants' intentions to vote at the next EU parliamentary elections. Considering the high percentage of 'No/I don't know' answers (69.9\%) to the item on voting intentions among adolescents (due to the low age they did not know whether they would be allowed to vote in the next elections) we considered voting intentions only in the sample of young adults. The association between the two measures was not significant and they were used separately in the analyses $\left[X^{2}(1,4302)=1.28, p=.26\right]$.

\section{Analyses}

The analyses were conducted separately for adolescents and young adults. Descriptive and univariate analyses (correlations and independent samples t-tests) were performed through the software SPSS 19. The hypotheses were tested through the macro PROCESS 2.16 for SPSS (Hayes, 2013). More specifically, models 4 and 8 of PROCESS allowed to test mediation models with multiple mediators operating in parallel (among adolescents and young adults). Mobility variables were inserted as independent variables and participation/

\footnotetext{
${ }^{2}$ In fact, long-term mobility was measured in both groups (adolescents and young adults). However, the frequency of long-term mobility among adolescents was very low $(M=1.56$ on a scale $1-5)$, with high value of kurtosis (3.06), that we preferred to consider these variables in the young adult sample only.
} 
Table 2. Descriptive statistics.

\begin{tabular}{|c|c|c|c|c|c|c|}
\hline \multirow[b]{2}{*}{ Variable (range) } & \multicolumn{3}{|c|}{ Adolescents (14-19 years) } & \multicolumn{3}{|c|}{ Young adults (20-30 years) } \\
\hline & $M(\mathrm{SD})$ & Skewness & Kurtosis & $M(\mathrm{SD})$ & Skewness & Kurtosis \\
\hline Short-term mobility (1-5) & $2.50(1.18)$ & .45 & -.66 & $2.78(1.18)$ & .22 & -.82 \\
\hline Long-term mobility (1-5) & & & & $1.78(1.05)$ & 1.39 & 1.34 \\
\hline European identification (1-5) & $3.52(.91)$ & -.54 & .28 & $3.61(.95)$ & -.67 & .22 \\
\hline Attitudes EU (1-5) & $3.65(.90)$ & -.51 & .18 & $3.65(.99)$ & -.57 & -.05 \\
\hline EU community-political (1-5) & $3.42(1.00)$ & -.33 & -.11 & $3.52(1.11)$ & -.44 & -.41 \\
\hline EU community-economic (1-5) & $3.48(.87)$ & -.33 & .29 & $3.34(1.02)$ & -.38 & -.19 \\
\hline EU community-history (1-5) & $2.96(.99)$ & -.12 & .02 & $3.03(1.02)$ & -.18 & -.15 \\
\hline $\begin{array}{l}\text { EU community-shared values } \\
(1-5)\end{array}$ & $3.74(.88)$ & -.53 & .37 & $3.91(.95)$ & -.83 & -.62 \\
\hline Participation EU (\% Yes) & $31.8 \%$ & & & $38.1 \%$ & & \\
\hline Voting intentions EU (\% Yes) & & & & $66.8 \%$ & & \\
\hline
\end{tabular}

Notes: For scale variables, means, standard deviation, Skewness and Kurtosis are reported. For the other variables, valid percentages among each age-group are reported.

voting intentions at EU level were inserted as dependent variables. European identification, positive attitudes toward the EU, and visions of EU were inserted as mediators. All the models were controlled for country, migrant status, gender and socioeconomic status. The country variable was recoded into seven dummy variables. The bootstrapping procedure with 5000 samples was used to estimate indirect effect. Confidence level for bias-corrected confidence intervals was $95 \%$.

\section{Results}

Descriptive statistics for the key-variables are presented in Table 2. The values for skewness and kurtosis of all the variables under study were acceptable (i.e., between -2 and +2; George \& Mallery, 2010) (Tables 3-5).

\section{The impact of cross-border mobility on participation on EU issues}

We first examined the impact of short-term mobility among adolescents. To this purpose, short-term mobility was introduced as independent variable and participation on EU issues was inserted as dependent variable. European identification, positive attitudes toward EU and visions of the EU were inserted as mediators. Table 6 provides the value of indirect effects. Short-term mobility showed a significant indirect effect on participation on EU issues through European identification and vision of the EU as a political community. The direct effect of short-term mobility on participation was significant (Figure $1^{3}$ ).

Among young adults, similarly to adolescents, short-term mobility had a positive indirect effect on participation on EU issues through European identification and vision of the EU as political community (Figure 2 and Table 7). The 
Table 3. Correlations between variables, among adolescents and young adults.

\begin{tabular}{lcccccccc}
\hline & 1. & 2. & 3. & 4. & 5. & 6. & 7. & 8. \\
\hline 1. Short-term mobility & - & $.55^{* *}$ & $.30^{* *}$ & $.26^{* *}$ & $.22^{* *}$ & $.07^{* *}$ & $.14^{* *}$ & $.13^{* *}$ \\
2. Long-term mobility & & - & $.18^{* *}$ & $.11^{* *}$ & $.16^{* *}$ & $.07^{* *}$ & $.08^{* *}$ & $.08^{* *}$ \\
3. European identification & $.11^{* *}$ & & - & $.49^{* *}$ & $28^{* *}$ & $.19^{* *}$ & $.24^{* *}$ & $.22^{* *}$ \\
4. Attitudes EU & $.13^{* *}$ & & $.40^{* *}$ & - & $.32^{* *}$ & $.20^{* *}$ & $.13^{* *}$ & $.26^{* *}$ \\
5. EU community-political & $.06^{* *}$ & & $.14^{* *}$ & $.21^{* *}$ & - & $.28^{* *}$ & $.26^{* *}$ & $.35^{* *}$ \\
6. EU community-economic & $.04^{*}$ & & $.13^{* *}$ & $.12^{* *}$ & $.27^{* *}$ & - & $.16^{* *}$ & $.19^{* *}$ \\
7. EU community-history & .04 & & $.13^{* *}$ & $.05^{*}$ & $.17^{* *}$ & $.13^{* *}$ & - & $.27^{* *}$ \\
8. EU community-shared & -.02 & & $.12^{* *}$ & $.12^{* *}$ & $.24^{* *}$ & $.26^{* *}$ & $.20^{* *}$ & - \\
$\quad$ values & & & & & & & &
\end{tabular}

Notes: Pearson's correlations are reported.

${ }^{*} p<.01 ;{ }^{* *} p<.001$; Correlations for young adults are presented above the diagonal, and correlations for adolescents are presented below the diagonal.

Table 4. Comparison between participants and non-participants, among adolescents.

\begin{tabular}{|c|c|c|c|}
\hline \multirow[b]{3}{*}{ Variable } & \multicolumn{2}{|c|}{ Participation EU } & \multirow[b]{3}{*}{$t$} \\
\hline & No & Yes & \\
\hline & $M(\mathrm{SD})$ & $M(\mathrm{SD})$ & \\
\hline Short-term mobility (1-5) & $2.52(1.16)$ & $2.44(1.21)$ & 2.09 \\
\hline European identification (1-5) & $3.48(.88)$ & $3.62(.93)$ & $4.68^{* *}$ \\
\hline Attitudes EU (1-5) & $3.64(.86)$ & $3.65(.98)$ & .29 \\
\hline EU community political (1-5) & $3.40(.97)$ & $3.47(1.01)$ & 2.20 \\
\hline EU community economic (1-5) & $3.48(.84)$ & $3.49(.92)$ & .42 \\
\hline EU community history (1-5) & $2.95(.96)$ & $2.96(1.05)$ & .46 \\
\hline EU community shared values (1-5) & $3.70(.87)$ & $3.84(.91)$ & $4.92^{* *}$ \\
\hline
\end{tabular}

Notes: Absolute values of $t$ are reported.

${ }^{*} p<.01 ;{ }^{* *} p<.001$.

Table 5. Comparison between participants and non-participants; comparison between voters and non-voters, among young adults.

\begin{tabular}{llccccc}
\hline & \multicolumn{3}{c}{ Participation EU } & \multicolumn{3}{c}{ Voting intentions EU } \\
\cline { 2 - 7 } & \multicolumn{1}{c}{ No } & \multicolumn{1}{c}{ Yes } & \multicolumn{3}{c}{$\begin{array}{c}\text { No/l don't } \\
\text { know }\end{array}$} & Yes \\
Variable & \multicolumn{1}{c}{$M(\mathrm{SD})$} & $M(\mathrm{SD})$ & $t$ & $M(\mathrm{SD})$ & $M(\mathrm{SD})$ & $t$ \\
\hline Short-term mobility (1-5) & $2.70(1.12)$ & $3.04(1.22)$ & $9.38^{* *}$ & $2.52(1.15)$ & $2.74(1.17)$ & $10.87^{* *}$ \\
Long-term mobility (1-5) & $1.68(1.01)$ & $1.99(1.12)$ & $9.09^{* *}$ & $1.75(1.00)$ & $1.78(1.08)$ & .99 \\
European identification (1-5) & $3.57(.92)$ & $3.72(.99)$ & $4.93^{* *}$ & $3.36(.97)$ & $3.75(.91)$ & $12.98^{* *}$ \\
Attitudes EU (1-5) & $3.70(.93)$ & $3.65(1.06)$ & 1.46 & $3.25(.93)$ & $3.85(.95)$ & $20.30^{* *}$ \\
EU community political (1-5) & $3.44(1.05)$ & $3.72(1.19)$ & $7.92^{* *}$ & $3.34(1.17)$ & $3.60(1.06)$ & $7.29^{* *}$ \\
EU community economic (1-5) & $3.32(1.00)$ & $3.35(1.07)$ & .88 & $3.30(1.02)$ & $3.35(1.02)$ & 1.55 \\
EU community history (1-5) & $2.94(.98)$ & $3.15(1.08)$ & $6.46^{* *}$ & $2.99(1.02)$ & $3.05(1.02)$ & 1.63 \\
EU community shared values & $3.89(.93)$ & $4.02(.94)$ & $4.56^{* *}$ & $3.70(.98)$ & $4.02(.90)$ & $10.91^{* *}$ \\
$\quad(1-5)$ & & & & & & \\
\hline
\end{tabular}

Note: Absolute values of $t$ are reported.

${ }^{*} p<.01 ;{ }^{* *} p<.001$.

positive direct effect of short-term mobility on participation was significant. However, a negative indirect effect of short-term mobility through the vision of the EU as an economic community also appeared. 
Table 6. Indirect effect between short-term mobility and participation (EU) among adolescents.

\begin{tabular}{lccc}
\hline & $b$ & SE & $95 \% \mathrm{Cl}$ \\
\hline European identification & .020 & .005 & $.0114 ; .0310$ \\
Attitudes EU & .001 & .003 & $-.0037 ; .0075$ \\
EU community-political & .003 & .002 & $.0001 ; .0085$ \\
EU community-economic & .000 & .001 & $-.0010 ; .0031$ \\
EU community-history & .000 & .001 & $-.0005 ; .0030$ \\
EU community-shared values & .001 & .002 & $-.0023 ; .0056$ \\
\hline
\end{tabular}

Note: If the confidence interval $(\mathrm{Cl})$ does not include 0 , it can be assumed that there is a statistically significant result.

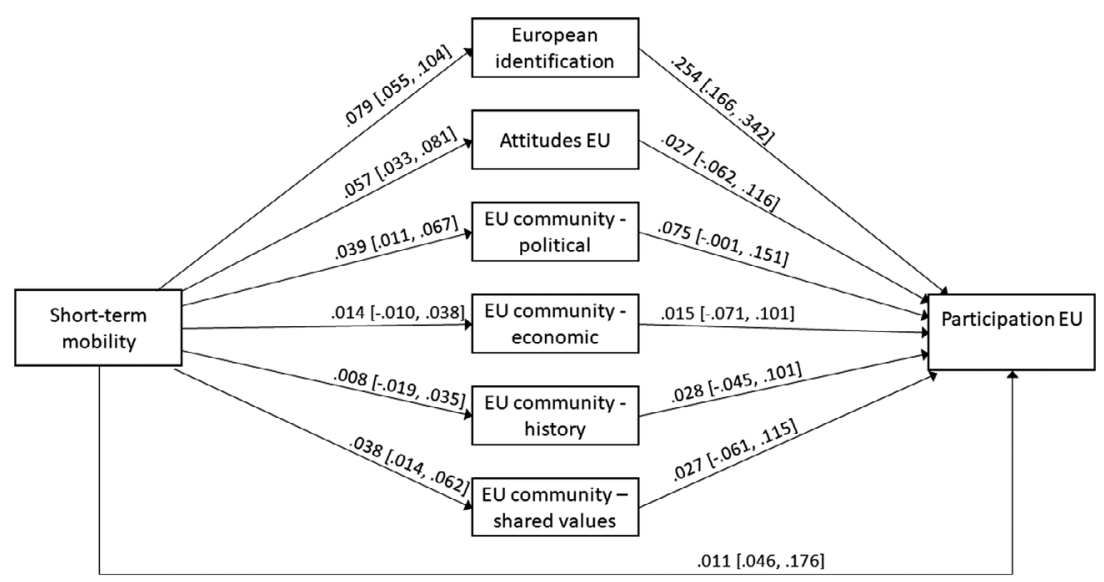

Figure 1. Short-term mobility and participation EU among adolescents.

Note: Coefficients and confidence intervals.

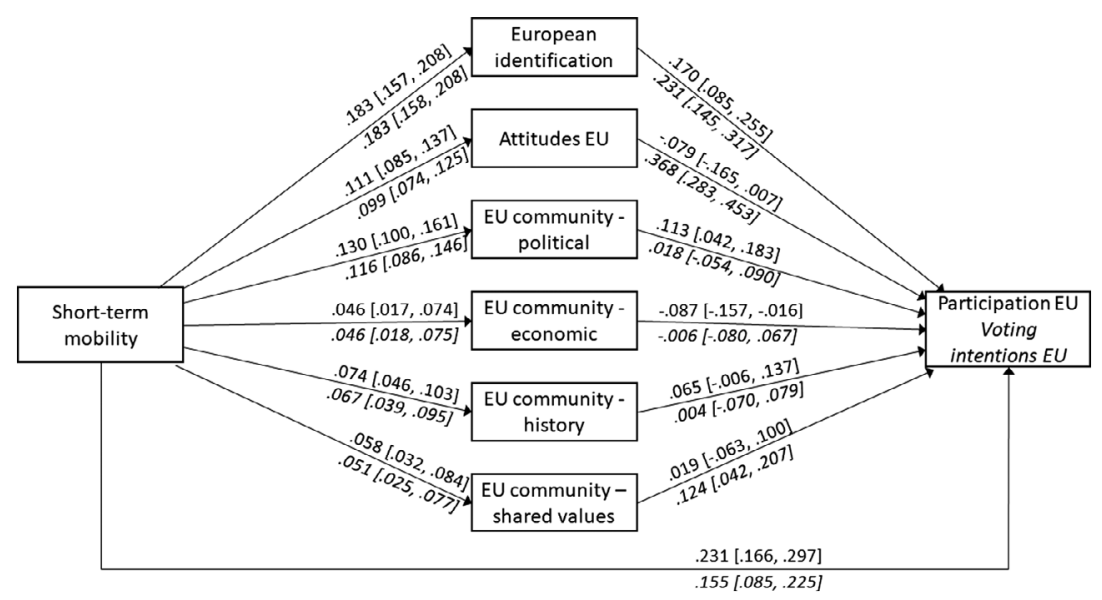

Figure 2. Short-term mobility and participation/voting intentions EU among young adults. Note: Coefficients and confidence intervals. 
The same model was tested for long-term mobility among young adults. Long term mobility showed a positive indirect effect on participation on EU issues through European identification and vision of the EU as a political community, and a negative indirect effect through vision of the EU as an economic community (Figure 3 and Table 8). The direct effect of long-term mobility on participation was significant.

\section{The impact of cross-border mobility on intentions to vote at EU parliamentary elections (young adults)}

For both short-term and long-term mobility, the model was tested also considering, as dependent variable, intention to vote at the next EU parliamentary elections. Short-term mobility showed an indirect effect on intention to vote

Table 7. Indirect effect between short-term mobility and participation/voting intentions EU among young adults.

\begin{tabular}{lcccc}
\hline & \multicolumn{2}{c}{ Participation EU } & \multicolumn{2}{c}{ Voting intentions EU } \\
\cline { 2 - 5 } & $b$ & $95 \% \mathrm{Cl}$ & $b$ & $95 \% \mathrm{Cl}$ \\
\hline European identification & .031 & $0144 ; .0481$ & .042 & $.0257 ; .0602$ \\
Attitudes EU & -.001 & $-0198 ; .0005$ & .037 & $.0250 ; .0507$ \\
EU community-political & .015 & $0054 ; 0262$ & .002 & $-.0065 ; .0108$ \\
EU community-economic & -.004 & $-.0099 ;-.0006$ & -.000 & $-.0045 ; .0031$ \\
EU community-history & .005 & $-.0001 ; .0118$ & .000 & $-.0051 ; 0054$ \\
EU community-shared & .001 & $-.0041 ; .0064$ & .006 & $.0018 ; .0130$ \\
$\quad$ & & & &
\end{tabular}

Note: If the confidence interval $(\mathrm{Cl})$ does not include 0 , it can be assumed that there is a statistically significant result.

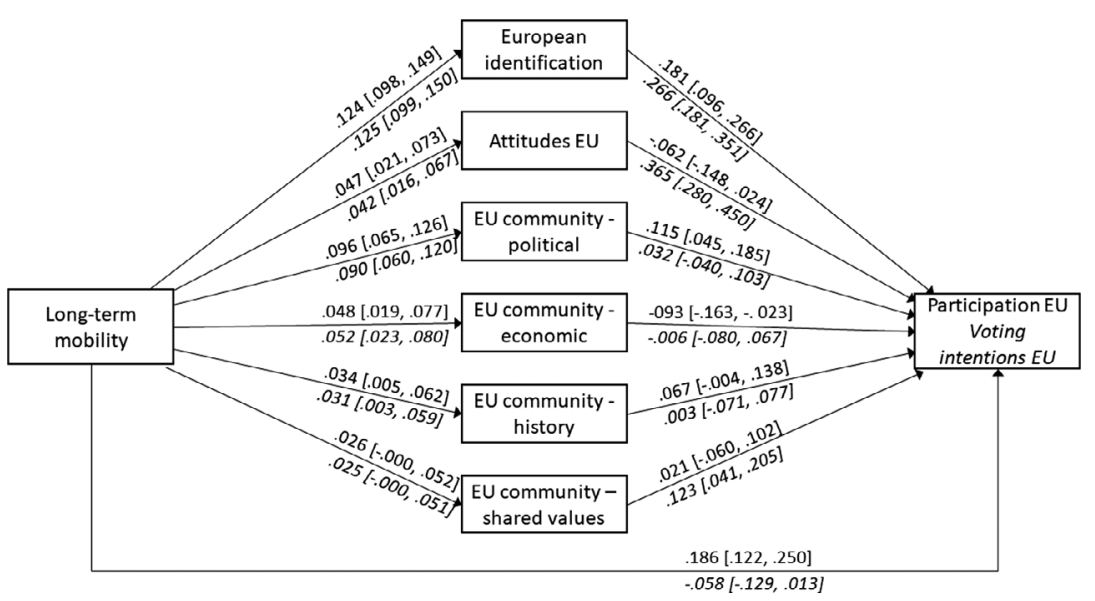

Figure 3. Long-term mobility and participation/voting intentions EU among young adults. Note: Coefficients and confidence intervals. 
Table 8. Indirect effect between long-term mobility and participation/voting intentions EU among young adults.

\begin{tabular}{lcccc}
\hline & \multicolumn{2}{c}{ Participation EU } & \multicolumn{2}{c}{ Voting intentions EU } \\
\cline { 2 - 5 } & $b$ & $95 \% \mathrm{Cl}$ & $b$ & $95 \% \mathrm{Cl}$ \\
\hline European identification & .022 & $.0118 ; .0352$ & .033 & $.0212 ; 0470$ \\
Attitudes EU & -.003 & $-.0087 ; .0008$ & .015 & $.0060 ; .0263$ \\
EU community-political & .011 & $.0042 ; .0206$ & .003 & $-.0039 ; .0095$ \\
EU community-economic & -.004 & $-.0108 ;-.0010$ & -.000 & $-.0050 ; .0036$ \\
EU community-history & .002 & $.000 ; .0071$ & .000 & $-.0023 ; .0031$ \\
EU community-shared & .000 & $-.0014 ; .0041$ & .003 & $.0001 ; .0082$ \\
$\quad$ & & & &
\end{tabular}

Note: If the confidence interval (Cl) does not include 0 , it can be assumed that there is a statistically significant result.

through European identification, positive attitudes toward the EU, and vision of the EU as a community of shared values (Table 7). Short term mobility maintained a significant direct effect on the intention to vote (Figure 2).

Similarly, long term-mobility showed an indirect effect on intention to vote through European identification, positive attitudes toward the EU, and vision of the EU as a community of shared values (Table 8 and Figure 3).

Finally, for the models with long-term mobility, we replicated the analyses considering also the moderator effect of the reason for long-term mobility (education/training vs. other). We introduced the reason for mobility as moderator of the relationship between mobility and the mediators. However, results were not significant, providing no support for a moderated mediation (data not shown).

\section{Discussion}

The findings of the study confirmed that both short-term and long-term mobility, as defined in this study, had a significant indirect effect on participation on EU issues, through European identification and vision of the ideal EU as a political community. Moreover, both short- and long-term mobility showed a significant indirect effect on the intention to vote at the next EU elections through European identification, positive attitudes toward the EU, and vision of EU as a community of shared values.

Our results largely confirmed our hypotheses about the relationship between mobility and psychological variables. The positive relationships between mobility and identification as European, and between mobility and positive attitudes toward EU, are consistent with previous research findings (Mitchell, 2012, 2015). Moreover, our results underlined the association between mobility and many dimensions of the vision of EU as a community, such as: historical, economic, political, shared values. The fact that also short-term mobility showed a significant effect supports its importance in adolescence and young adulthood. No evidence was found for the moderation role played by the reason for long-term 
mobility (educational reason vs. non educational), suggesting that traveling for non-educational reasons may also provide important contact opportunities.

Second, the results partially confirmed our hypotheses about the relationship between psychological processes (i.e., the mediators) and the participation variables. As regards the impact of identification as European, our results were consistent with the above-mentioned literature that linked group identification with participation (e.g., Fowler \& Kam, 2007; Talò et al., 2014). Moreover, positive attitudes toward EU showed a significant effect on the intention to vote at the next EU elections, suggesting that the intention to vote at the EU election can often be related with pro-EU attitudes. Consistent with our hypotheses, visions of EU as political community and community of shared values were also significantly and positively related to our dependent variables, suggesting that these two visions are particularly important in supporting young people' political actions. Moreover, vision of EU as historical community was not a significant mediator in any of the models, confirming that having a heritage-based vision of EU is not associated with participation (e.g., La Barbera, 2015). However, the vision of EU as economic community showed a significant negative effect of participation on EU issue, partially suppressing the positive effect of short term mobility on participation. One possible explanation to this result is that young people may think, from a'free-rider' logic (e.g., Olson, 1965), that they can instrumentally receive benefits from such economic community even without any participatory effort.

Our findings contribute to the explanation of the relationship between young people's cross-border mobility and their engagement as European citizens, and have implications for the development of international mobility programmes for adolescents and young adults, indicating that also short term programmes and initiatives may be effective in enhancing young people European citizenship.

Some limitations in the assessment of our variables should be addressed by future research. For example, in this study we did not distinguish the mobility situation of each participant, assessing the combination of country of origin and country of destination, and our measure of migrant status did not consider second generation migrants. Moreover, the different kinds of mobility were measured through single items, not allowing reliability testing. Participation on EU issue was measured through a single item, without considering the different effect on different forms of participation.

The quite high level of reported income (that is coherent with the characteristics of young European movers) suggests that individuals with less resources were not well represented in our sample. This study adopted a cross-sectional design and did not allow to fully ascertain the causal direction between variables. For example, cross-border mobility might be more likely among adolescents and young adults who already feel more Europeans (see for example Kuhn, 2012; Wilson, 2011). Similarly, participation experiences on EU issues, which also 
depend on personal resources and socio-economic status, might themselves strengthen a vision of the EU as a political and shared values community.

Moreover, the fact that mobility often maintains a direct effect on participation, suggests that such relationship can be explained by further mechanisms that were not considered in the present study. The longitudinal study which is planned as part of the same CATCH-EyoU project, will be able to respond to some of these questions.

\section{Acknowledgements}

The author(s) would like to thank Isabel Menezes, Erik Amnå, Peter Noack, Petr Macek, Veronika Kalmus, Shakuntala Banaji, Frosso Motti-Stefanidi, for the data which were collected by their teams to be used in this paper. Signe Opermann acknowledges the Estonian Research Council for funding her postdoctoral fellowship under Grant PUTJD570.

\section{Disclosure statement}

No potential conflict of interest was reported by the authors.

\section{Funding}

The research reported in this paper was funded by the European Union, Horizon 2020 Programme, Constructing AcTiveCitizensHip with European Youth: Policies, Practices, Challenges and Solutions (www.catcheyou.eu), grant agreement number 649538. The views and opinions expressed in this publication are the sole responsibility of the author(s) and do not necessarily reflect the views of the European Commission.

\section{ORCID}

Davide Mazzoni (iD) http://orcid.org/0000-0001-6607-5636

Cinzia Albanesi (D) http://orcid.org/0000-0001-8240-6159

Pedro D. Ferreira (D) http://orcid.org/0000-0002-5010-7397

Elvira Cicognani (iD http://orcid.org/0000-0002-8653-290X

\section{References}

Albanesi, C., Cicognani, E., \& Zani, B. (2007). Sense of community, civic engagement and social well-being in Italian adolescents. Journal of Community \& Applied Social Psychology, 17, 387-406. doi:10.1002/casp.903

Allport, G. W. (1954). The nature of prejudice. New York, NY: Addison-Wesley.

Amir, Y. (1969). Contact hypothesis in ethnic relations. Psychological Bulletin, 71, 319-342. doi:10.1037/h0027352

Cicognani, E. \& Zani, B. (2015). Social and psychological factors influencing political and civic participation. In M. Barrett \& B. Zani (Eds). Political and civic engagement. Multidisciplinary perspectives (pp. 124-145). London: Routledge.

Deutsch, K., Burrell, S., Kann, R., \& Lee, M. (1967). Political community and the North Atlantic area. New York, NY: Greenwood Press. 
Ellemers, N. (1993). The influence of socio-structural variables on identity management strategies. European Review of Social Psychology, 4, 25-57. doi:10.1080/14792779343000013

EPRS - European Parliamentary Research Service. (2014). 2014 European elections. Profile of voters and non-voters in each EU Member State. European Parliament. Public Opinion Monitoring Unit. Retrieved from http://www.europarl.europa.eu

European Commission. (2011). The EU's global approach to migration and mobility. Retrieved from http://eur-lex.europa.eu

European Commission. (2015). Erasmus facts, figures \& trends. The European Union support for student and staff exchanges and university cooperation in 2012-2013. Luxembourg: Publications Office of the European Union.

Eurostat. (2015). People in the EU: Who are we and how do we live?. Retrieved from http:// ec.europa.eu/eurostat/

Fernández, J., Eigmüller, M., \& Börner, S. (2016). Domestic transnationalism and the formation of pro-European sentiments. European Union Politics, 17, 457-481. doi:10.1177/1465116516633536

Fligstein, N. (2008). Euroclash: The EU, European identity and the future of Europe. Oxford: Oxford University Press.

Fowler, J. H., \& Kam, C. D. (2007). Beyond the self: Social identity, altruism, and political participation. Journal of Politics, 69, 813-827. doi:10.1111/j.1468-2508.2007.00577.x

Gaertner, S. L., \& Dovidio, J. F. (2000). Reducing intergroup bias: The common ingroup identity model. Philadelphia, PA: Psychology Press.

Gaertner, S. L., Dovidio, J. F., \& Bachman, B. A. (1996). Revisiting the contact hypothesis: The induction of a common ingroup identity. International Journal of Intercultural Relations, 20, 271-290. doi:10.1016/0147-1767(96)00019-3

George, D., \& Mallery, M. (2010). SPSS for windows step by step: A simple guide and reference, 17.0 update (10a ed.). Boston, MA: Pearson.

Gerner, M. E., \& Perry, F. (2000). Gender differences in cultural acceptance and career orientation among internationally mobile and non-internationally mobile adolescents. School Psychology Review, 29, 267-283.

Hauvette, M. (2010). Temporary youth migration and European identity. In D. Cairns (Ed.), Youth on the move. European youth and geographical mobility (pp. 47-58). Wiesbaden: Springer.

Hayes, F. A. (2013). Introduction to mediation, moderation, and conditional process analysis: A regression-based approach. New York, NY: Guilford Publications.

King, R., \& Ruiz-Gelices, E. (2003). International student migration and the European 'year abroad': Effects on European identity and subsequent migration behaviour. International Journal of Population Geography, 9, 229-252. doi:10.1002/ijpg.280

Kuhn, T. (2012). Why educational exchange programmes miss their mark: Cross-border mobility, education and European identity. Journal of Common Market Studies, 50, 994-1010. doi:10.1111/j.1468-5965.2012.02286.x

La Barbera, F. (2015). Framing the EU as common project vs. common heritage: Effects on attitudes toward the EU deepening and widening. The Journal of Social Psychology, 155, 617-635. doi:10.1080/00224545.2015.1041446

La Barbera, F., Cariota Ferrara, P., \& Boza, M. (2014). Where are we coming from versus who we will become: The effect of priming different contents of European identity on cooperation. International Journal of Psychology, 49, 480-487. doi:10.1002/ ijop.12073

Llurda, E., Gallego-Balsà, L., Barahona, C., \& Martin-Rubió, X. (2016). Erasmus student mobility and the construction of European citizenship. The Language Learning Journal, 44, 323-346. doi:10.1080/09571736.2016.1210911 
Maiworm, F., \& Over, A. (2014). Student mobility and European Identity. Bonn: DAAD.

Merkwan, J. V., \& Smith, T. B. (1999). Tolerance and racial identity among foreign sojourners: Testing the contact hypothesis. Psychological Reports, 85, 170-170. doi:10.2466/ PR0.85.5.170-170

Mitchell, K. (2012). Student mobility and European identity: Erasmus study as a civic experience?. Journal of Contemporary European Research, 8, 490-518.

Mitchell, K. (2015). Rethinking the 'Erasmus effect' on European identity. Journal of Common Market Studies, 53, 330-348. doi:10.1111/jcms.12152

Muxell, A. (2009). EU movers and politics: Towards a fully-fledged European citizenship? In E. Recchi, \& A. Favell (Eds.), Pioneers of European integration: Citizenship and mobility in the EU (pp. 156-178). Cheltenham: Edward Elgar.

Olson, M. (1965). The logic of collective action. Cambridge, MA: Harvard University Press.

Papatsiba, V. (2005). Student mobility in Europe: An academic, cultural and mental journey? Some conceptual reflections and empirical findings. International Perspectives on Higher Education Research, 3, 29-65. doi:10.1016/S1479-3628(05)03003-0

Pickup, L., Biosca, O., Franckx, L., Konings, H., Mayeres, I., Plaut, P., ... Van Hulsel, M. (2015). MIND-SETS: A new vision on European mobility. Deliverable 2.1A of the IND-SETS project. Brussels: European Commission Directorate General for Research.

Recchi, E. (2014). Pathways to European identity formation: A tale of two models. Innovation: The European Journal of Social Science Research, 27, 119-133. doi:10.1080 /13511610.2013.873709

Roeder, A. (2011). Does mobility matter for attitudes to Europe? A multi-level analysis of immigrants' attitudes to European unification. Political Studies, 59, 458-471. doi:10.1111/j.1467-9248.2010.00871.x

Sigalas, E. (2010). Cross-border mobility and European identity: The effectiveness of intergroup contact during the ERASMUS Year Abroad. European Union Politics, 11, 241-265. doi:10.1177/1465116510363656

Siklodi, N. (2015). Active citizenship through mobility? Students' perceptions of identity, rights and participation in the EU. Citizenship Studies, 19, 820-835. doi:10.1080/1362 1025.2015.1053792

Spannring, R., Wallace, C., \& Datler, G. (2008). What leads young people to identify with Europe? An exploration of the impact of exposure to Europe and political engagement on European identity among young Europeans. Perspectives on European Politics and Society, 9, 480-498. doi:10.1080/15705850802416929

Stronkhorst, R. (2005). Learning outcomes of international mobility at two Dutch institutions of higher education. Journal of Studies in International Education, 9, 292315. doi:10.1177/1028315305280938

Talò, C., Mannarini, T., \& Rochira, A. (2014). Sense of community and community participation: A meta-analytic review. Social Indicators Research, 117, 1-28. doi:10.1007/ s11205-013-0347-2

Thorpe, C. (2008). The distinguishing function of European identity: Attitudes towards and visions of Europe and the European Union among young Scottish adults. Perspectives on European Politics and Society, 9, 499-513. doi:10.1080/15705850802416945

Tran, L. T. (2016). Mobility as 'becoming': A Bourdieuian analysis of the factors shaping international student mobility. British Journal of Sociology of Education, 37, 1268-1289. doi:10.1080/01425692.2015.1044070

Wilson, I. (2011). What should we expect of "Erasmus generations"? Journal of Common Market Studies, 49, 1113-1140. doi:10.1111/j.1468-5965.2010.02158.x 